\title{
Importance of Linseed Crops in Agricultural Sustainability
}

\author{
Santosh Kumar*, J.K. Singh and Akhilesh Vishwakarma \\ Department of Agronomy, Institute of Agricultural Sciences, Banaras Hindu University, \\ Varanasi - 221005, Uttar Pradesh, India \\ *Corresponding author
}

\section{Keywords}

Flaxseed, Omega-3 fatty acid, Vitamin

E, Protein,

Carbohydrates

Article Info

Accepted:

10 November 2018

Available Online:

10 December 2018

\section{A B S T R A C T}

The country is the largest producer of oilseeds in the world and oilseed sector occupies an important position in the agricultural industry as well as in trade and national economy of the country. Oilseeds are among the major crops that are grown in the country apart from cereals. Linseed is an important industrial and edible oil and fiber producing crop. It also being as medicinal plant is rich in oil (41\%), protein (20\%), dietary fiber (28\%), contains $7.7 \%$ moisture and $3.3 \%$ ashes. It has a high percentage of essential fatty acids, $75 \%$ polyunsaturated fatty acids, $57 \%$ alphalinolenic acid, which is an omega-3 fatty acid, and $16 \%$ linoleic acid, which is an omega-6 fatty acid (Morris, 2005). In terms of acreage, production and economic value, these crops are second only to food grains. India is the fifth largest vegetable oil economy in the world next only to USA, China, Brazil and Argentina, and has an annual turnover of about ${ }^{`} 80000$ crore. India accounts for $12-15$ per cent of global oilseeds area, 7-8 per cent of oilseeds production, 6-7 per cent of vegetable oils production, 9-12 per cent of vegetable oils import and 9-10 per cent of the edible oils consumption (Jha et al., 2012). Linseed is an important industrial and edible oil and fiber producing crop. It also being as medicinal plant is rich in oil (41\%), protein $(20 \%)$, dietary fiber (28\%), contains $7.7 \%$ moisture and $3.3 \%$ ashes. It has a high percentage of essential fatty acids, $75 \%$ polyunsaturated fatty acids, $57 \%$ alphalinolenic acid, which is an omega-3 fatty acid, and 16\% linoleic acid, which is an omega-6 fatty acid (Morris, 2005). Flaxseed or linseed (Linum usitatissimum L.) comes from the flax plant, an annual herb. The main importance of flaxseed is in the human nutrition sector because it is emerging as an important functional food ingredient thanks to the content of active compounds, pointed to provide health benefits.

\section{Introduction}

Oil seeds occupy an important position in the agricultural economy of India. Among the different oilseeds crops grown in country, linseed (Linum usitatissimum L.) is considered the most important oilseed crop of India and stands next to rapeseed-mustard in winter season (Rabi) oilseed crop in area and production. Linseed is an important industrial and edible oil and fiber producing crop. It also being as medicinal plant is rich in oil (41\%), protein $(20 \%)$, dietary fiber $(28 \%)$, contains $7.7 \%$ moisture and $3.3 \%$ ashes. It has a high percentage of essential fatty acids, $75 \%$ polyunsaturated fatty acids, $57 \%$ alphalinolenic acid, which is an omega-3 fatty acid, and $16 \%$ linoleic acid, which is an 
omega-6 fatty acid (Morris, 2005). Cultivation region of the world, water stress, high temperature and disease occurrence affect growth parameters. For example, flax seedlings can withstand a temperature of -4 ${ }^{\circ} \mathrm{C}$, but very high temperatures (exceeding 32 ${ }^{\circ} \mathrm{C}$ ) could shorten stem length and flowering period, thereby affecting fiber or seed yield. The country is the largest producer of oilseeds in the world and oilseed sector occupies an important position in the agricultural industry as well as in trade and national economy of the country. Oilseeds are among the major crops that are grown in the country apart from cereals. In terms of acreage, production and economic value, these crops are second only to food grains. India is the fifth largest vegetable oil economy in the world next only to USA, China, Brazil and Argentina, and has an annual turnover of about ' 80000 crore. India accounts for 12-15 per cent of global oilseeds area, 7-8 per cent of oilseeds production, 6-7 per cent of vegetable oils production, 9-12 per cent of vegetable oils import and 9-10 per cent of the edible oils consumption (Jha et al., 2012). The plant is native to west Asia and the Mediterranean. As the source of linen fiber flax has been cultivated since at least $5000 \mathrm{BC}$, today it is mainly grown for its oil (Berugland, 2002; Oomah, 2001). According to the last available issue of FAO statistics (http://faostat3.fao.org/ faostat-gateway), in 2013 the global world linseed production (area harvested) was 2,252,104 ha The significant linseed flax cultivation areas were located in Canada $(412,000$ ha),- the "traditional" leader of linseed cultivation, followed by Russian Federation (410,000 ha) and Kazakhstan $(384,300$ ha) the two countries indicating the highest stable increase in linseed production during last five years, India (338,000 ha), China (312,890 ha). Currently India's total oilseed production is expected to grow 6.4 per cent to 37 million tons in 2013-14. Strong market prices for oilseeds and yield improvements will likely increase oilseed crush and push total oil meal production to 17.8 million tons, an increase of 6 per cent in 2013-14. Growing international demand for animal feed is also expected to push Indian oil meal exports to 5.6 million tons. Edible vegetable oil production and consumption are expected to increase to 7.6 million tons and 18.6 million tons, respectively. Flaxseed, or Linseed (Linum Usitatissimmum), popularly known as Alsi, Jawas, Aksebija in Indian languages, is a blue flowering rabi crop and a member of family Linaceae. Annual production of flax was 3.06 million tons and Canada is the world's largest producer of flax (about 38\% of total production) (Anonymous, 2000). Globally, Flaxseed is grown as either oil crop or a fiber crop with fiber linen derived from the stem of fiber varieties and oil from the seed of linseed varieties (Diederichsen $e t$ al., 2003; Vaisey-Genser et al., 2003). The spherical fruit capsules contain two seeds in each of five compartments. The seed is flat and oval with a pointed tip. One is small seeded having more oil content, developed in South-western Asia (India) and the other is bold seeded, suitable for fiber production and developed in the Mediterranean region. In India, linseed cultivated about 4.68 lakh ha and total linseed production is 1.63 lakh tones (2007-08). Linseed is an important rabi oilseed crop of eastern Uttar Pradesh, Madhya Pradesh, Chhattisgarh, Maharashtra, Odisha and Bihar. This was facilitate by a relatively protection umbrella of higher import duties on the import of edible oil of order of $65 \%$ on palm oil, the commonly imported oil. The yellow revolution symbolizes the will country to revolve a problem which evolved solution for a long time. There has been a continuous decline in linseed area in the country during the last four decades so to sustain linseed production mainly in irrigated area. The cultivation of linseed is restricted mostly to marginal and sub marginal land under restricted supply of fertilizer and irrigation, 
lack of improved varieties and untimely sowing, resulting in low crop yield. The linseed crop maintained its increasing trend in productivity while, the area registered the declining trend resulting in stagnant production. The decrease in area might be due to socio-economic factors as the per capita holding is shrinking owing to population increase, thereby pressing the growers to grow other crops for their sustenance. In addition to this, improper selection of varieties in this region, also affects the crop yield. At present there is a tremendous scope for increasing the yield of linseed with the use of multi-character high yielding varieties. Among the different practices to obtain higher crop yield with suitable agro technique under different agroclimatic zone, The production potentiality of linseed has tremendous potential to increase productivity per unit area by using high yielding.

In the global scale, linseed competes for its place in agricultural space with soybean, as a major oilseed crop, while in Europe also with oilseed rape. As a result of the low level of linseed yield, similarly as in the case of field pea, a progressive marginalization of these species can be observed in cultivation in favor of soybean (world) and oilseed rape (Europe) as the leading oilseed crops which provide the largest amounts of plant protein in extracted meal for livestock (Klimek and Zazac, 2009). This adverse trend, on the one hand, reduces biodiversity in agriculture and on the other hand, it introduces the cultivation of GMO varieties of soybean and oilseed rape. In the last reporting period -2009 , Canada had the highest share in the production of linseed seed across the world $-43.8 \%$, followed by China $15.0 \%$, India $-7.95 \%$, USA $-8.89 \%$, and Ethiopia $-7.10 \%$, whereas Europe accounts for $12.1 \%$ of this production. Ethiopia's linseed acreage has increased significantly as a result of broad-based research on local varieties and ecotypes, which have been confronted, in terms of their productivity and seed oil content, with the leading varieties supplied from Canada and the USA, the countries being the scientific and financial partners for this project (Wakjira et al., 2004). In these both countries from the NorthAmerican agricultural district of the world, seed yield of linseed is systematically growing, thereby the total share of these two countries in global linseed production exceeds $50 \%$, thus making them leading exporters of this agricultural produce. In Canada, linseed ranks sixth in importance among agricultural crops (Johnston et al., 2002).

\section{Differentiation of fiber flax and oilseed flax}

Flax cultivars have been selected for production of either fiber (fiber flax) or oil (oilseed flax). Location of production, climatic adaptation, and morphology of these types now differ considerably. Oilseed-type plants are usually shorter, have more branches, and produce more seeds, while fiber flax types are generally taller, have few branches, and have been selected for fiber (Gill, 1987). Best fibers from flax, derived as part of the phloem, are long $(4 \mathrm{~cm})$, have high tensile strength, and have a high quality of cellulose (Deyholos, 2006). Fine flax fibers are used for linens and textiles, while coarser fibers are used for nonwoven textiles and twine. Both flax types have a short tap root system with fibrous branches. Flax is relatively shallow rooted, with only 4-7\% of root mass deeper than 60 cm (Gan et al., 2009). The 202,000 ha of fiber flax are mainly located in China, Russia, Egypt, and near the northwestern European coast (Vromans, 2006; Green et al., 2008). For oilseed production, the straw is considered an impediment during harvest and for subsequent seeding operations and until recently has been burned. The majority of flax in North America is grown for the oil. Flaxseed or linseed (Linum usitatissimum L.) comes from the flax plant, an annual herb. The main importance of 
flaxseed is in the human nutrition sector because it is emerging as an important functional food ingredient thanks to the content of active compounds, pointed to provide health benefits. Typical chemical analyses of flaxseed fibre are mentioned in Table 1.

\section{Nutrients composition of flaxseed and health benefits}

Flaxseed is well-known for the content of chemical compounds with specific biological activity and functional properties: polyunsaturated fatty acids (PUFA) omega-3 family, soluble dietary fibers, lignans, proteins and carbohydrates. However, it is constituted by few levels of adverse health compounds such as Cadmium, protease inhibitors and cyanogenic compounds (Rubilar et al., 2010). An analysis of brown Canadian flax averaged $41 \%$ fat, $20 \%$ protein, $28 \%$ total dietary fibre, $7.7 \%$ moisture and $3.4 \%$ ash, which is the mineral-rich residue left after samples are burned (Morris et al., 2007 and Singh et al., 2011). The composition of flax can vary with genetics, growing environment, seed processing and method of analysis.

\section{Omega-3 fatty acids in flaxseed and health benefits}

Of all lipids in flaxseed (approximately 30\%), $53 \%$ are $\alpha$-linolenic acid (ALA), $17 \%$ linoleic acid (LA), 19\% oleic acid, 3\% stearic acid, and $5 \%$ palmitic acid, which provides an excellent n-6: $n-3$ fatty acid ratio of approximately 0.3:1 (Simopoulos, 2002). Therefore, the seed may be an alternative for supplying this fatty acid to populations concentrated in regions of the world where there is not large access to marine foods, which are the best sources of n-3 fatty acids (El-Beltagi et al., 2007). The tissue's fatty acid composition is not homogeneous. The linolenic acid contents in embryos, testa, and endosperm are all higher than that in the embryo axis. ALA is classified as an omega- 3 fatty acid, a group that also includes longchain metabolites of ALA (Kris-Etherton et al., 2000). Diet-induced changes in the polyunsaturated fatty acid composition of a cell membrane have an impact on the cell's function, partly because these fatty acids represent a reservoir of molecules that plays important role in inter or intra cellular signaling pathway. In particular, dietary omega- 3 fatty acids compete with the omega- 6 family of dietary polyunsaturated fatty acids for incorporation into all cell membranes. (Calder PC, 2006; Healy et al., 2000) Arguably, the most important of all cellular polyunsaturated fatty acids is the omega- 6 family member arachidonic acid. These compounds possess a range of activities, including activation of leukocytes and platelets, regulation of gastric secretions, induction of brunch constriction, upward movement of sperms from vagina to uterus and signaling of pain in nerve cells. The importance of these compounds in health and disease is evident by the range of pharmaceutical products that target their biosynthesis or action (Celotti et al., 2003). Similarly, the enrichment of monocyte membranes with omega-3 fatty acids results in the synthesis and secretion of reduced quantities of cytokines (e.g., tumour necrosis factor- $\alpha$, interleukin-1 $\beta$ ) that are involved in the amplification of the inflammatory response (Novak et al., 2003; Caughey et al., 1996).

Omega-3 fatty acids can also affect the function of membrane-associated proteins that are in direct contact with the lipid bilayer of cell membranes. The retinal protein rhodopsin is an example of this phenomenon (San Giovanni et al., 2005). Population studies have shown an association between lignin consumption and a lower risk of cardiovascular disease, although it is unclear 
at this time as to whether lignans are responsible for this effect or whether the effect is due to other constituents found in high lignin foods (Peterson et al., 2010).

\section{Proteins in flaxseed and health benefits}

Like all vegetables, flaxseed proteins have techno-functional properties that affect their behavior in a food system through interaction with other ingredients. These properties are mainly dependent on their hydration mechanisms for solubility and water /oil retention capacity. The amino acid pattern of flax protein is similar to that of soybean protein, which is viewed as one of the most nutritious of the plant proteins Rabetafika et al., (2011). Flaxseeds are not considered a source of complete proteins because the lack of some essential amino acids, necessarily introduced from the diet. Flaxseed grain and flaxseed paste contain about $21 \%$ and $34 \%$ protein respectively and may varies with the genetic and environmental factors Chung et al., (2005). Cool climates usually result in high oil and low protein content in the seeds. Flaxseed has two major storage proteins, a predominant salt soluble fraction with high molecular weight (11-12S; globulin; $18.6 \%$ nitrogen) and a water soluble basic component with low molecular weight (1.6- 2S; albumin; $17.7 \%$ nitrogen) (Chung, et al., 2005). Flaxseed has a favorable ratio of amino acids with Lysine, Threonine and Tyrosine as the limiting amino acids. Furthermore, it is a good source of sulfur amino acids (Metionine and Cysteine) and of branched chain amino acids (Oomah et al., 2007).

\section{Carbohydrates in flaxseed and health benefits}

Flax is low in carbohydrates (sugars and starches), providing only 1 gram (g) per $100 \mathrm{~g}$. For this reason, flax contributes little to total carbohydrate intake; it's recommended for people with specific diseases. Flaxseed polysaccharide is composed of two major fractions: a neutral arabinoxylan (75\%) and an acidic rhamnogalacturonan (25\%). The arabinoxylan is composed mainly of xylose, arabinose and galactose and the rhamnogalacturonan consists of L-rhamnose, D-galactose, D-galacturonic and L-fucose acid. Considerable and significant variations exist in monosaccharide composition, carbohydrate yield and quality among accessions from the world Collection of flaxseed (Ho et al., 2007).

\section{Micronutrients in flaxseed and health benefits}

Flaxseeds are a source of many vitamins and minerals as calcium, magnesium and phosphorus. It is of great importance, being that a $30 \mathrm{~g}$ portion of the seed constitutes $7 \%$ to $30 \%$ of the Recommended Dietary Allowances (RDAs) for these minerals (Singh et al., 2011). The most abundant vitamins constituting flaxseed are tocopherols $(\alpha-, \beta-$, and $\gamma$ - forms) and niacin. The tocopherols occur in $\alpha$ (alpha), $\beta$ (beta), $\gamma$ (gamma) and $\delta$ (delta) forms determined by the number and position of methyl groups on the chromanol ring. Alpha-tocopherol is the form of vitamin $\mathrm{E}$ that is preferentially absorbed and accumulated in humans instead the monomethylated form gamma- tocopherol is the most prevalent form of vitamin $\mathrm{E}$ in oils. Vitamin E, a fat-soluble vitamin, is present in flaxseed, predominantly, in the isomer $\gamma$ tocopherol. Antioxidant nutrients like vitamin E protect cell constituents from the damaging effects of free radicals that, if unchecked, might contribute to cancer development. Vitamin E might also block the formation of carcinogenic nitrosamines formed in the stomach from nitrites in foods and protect against cancer by enhancing immune function (Winter et al., 2013) Furthermore, vitamin E promotes sodium excretion in the urine which 
may helps lower blood pressure and helps lower the risk of heart disease, some types of cancer and Alzheimer disease.

\section{What is flaxseed fiber?}

Flaxseed fibre is a fine-milled flaxseed meal that is produced from the milling of flaxseed flake. Flaxseed flake is the product that remains after the cold extraction of the oil from flaxseed/linseed, and is sometimes referred to as de-fatted flaxseed. With the appearance of bran flakes, flaxseed flake can be milled to various degrees of coarseness, from a coarse meal to fine flour. Flaxseed fibre is a high quality, organic, natural, unrefined whole food product that is naturally gluten free with a shelf life of two years, as reported by the manufacturers. This hypothesis needs to be borne out by scientific experimentation. This paper summarizes on an introductory level, the nutritional attributes and reported health benefits of flaxseed fibre and lists its current potential applications in the food and dietary supplement industries.

\section{Linseed health benefits}

\section{A lower risk for heart disease}

Linseed oil helps to prevent arteriosclerosis. It makes blood platelets less sticky due to the conversion of linseed oil's Alpha-Linolenic Acid to Eicosapentaenoic Acid (EPA) and Series3 Prostaglandin's. Linseed Oil lowers elevated Blood pressure in hypertension suffers due to the presence of a substance very similar chemically to Prostaglandin E1. Epidemiologic and experimental data have provided evidence for a beneficial effect of omega-3 fatty acids in the prevention of Cardiovascular Disease. In 2002, the American Heart Association released a scientific statement endorsing the use of omega-3 fatty acids in both primary and secondary prevention (Etherton et al., 2002).

\section{Prevention of some forms of cancer}

Linseed contains dietary fibre and omega-3 fats in the form of ALA, which can help reduce the risk of cancer. Furthermore, study on women newly diagnosed with breast cancer showed a slowing of tumor growth with the addition of Linseed or flax to their diet. In 2009 a trial found that a supplement of eicosapentaenoic acid helped cancer patients retain muscle mass (Ryan et al., 2009). In general it contributes to the reduction of biochemical factors associated to cancer. (Kimura, 2001). Diabetes Studies showed that linseed lowers blood glucose in healthy, young adults. The effect of flax in the diets of people with type 2 diabetes is currently being investigated. Studies in older adults show eating linseed helps increase the frequency of bowel movements and relief from constipation. Linseed Oil often improves the function of the liver.

\section{Linseed Oil}

It is useful in the treatment of some cases of Edema. Linseed Oil can improve eyesight and colour perception. DHA plays an important role in the formation, development, and working of the brain and retina (Sangiovanni et al., 2005).Hair Linseed oil has a number of health benefits such as helping cure dandruff and helping heal any sprains or bruises (Bryan et al., 2010). Linseed oil may alleviate some cases of Alopecia Areata. 1 tablespoon of Flax seed oil daily can vastly improve the condition of dull hair.

\section{Immune system: treatment of immune disorders}

Linseed oil also play a role for improving immune function, containing alpha-linoleic acid and lignin have demonstrated a beneficial impact by affecting immune cells and immune response mediators, such as eicosanoids and 
cytokines through these mechanisms, linseed may play an important role in the clinical

management of autoimmune diseases and certain hormone and prostate.

Table.1 Typical chemical analysis of flaxseed fibre

\begin{tabular}{|c|c|c|}
\hline $\begin{array}{l}\text { Nutritional } \\
\text { Content }\end{array}$ & $\begin{array}{l}\text { Quantity per serving } \\
\text { (5g) }\end{array}$ & $\begin{array}{l}\text { Quantity per } \\
\text { 100g }\end{array}$ \\
\hline Energy & $82 \mathrm{kj}$ & 1635 \\
\hline Protein & $1.6 \mathrm{~g}$ & $32 \mathrm{~g}$ \\
\hline Total fat & $0.5 \mathrm{~g}$ & $10 \mathrm{~g}$ \\
\hline Saturated & $0.02 \mathrm{~g}$ & $0.4 \mathrm{~g}$ \\
\hline Monosaturated & $0.08 \mathrm{~g}$ & $1.5 \mathrm{~g}$ \\
\hline Polyunsaturated & $0.35 \mathrm{~g}$ & $7 \mathrm{~g}$ \\
\hline Omega 3(ala) & $0.25 \mathrm{~g}$ & $5 \mathrm{~g}$ \\
\hline $\begin{array}{l}\text { Total } \\
\text { carbohydrates }\end{array}$ & $2.18 \mathrm{~g}$ & $43.6 \mathrm{~g}$ \\
\hline Sugar & $0.07 \mathrm{~g}$ & $1.4 \mathrm{~g}$ \\
\hline Dietary fibres & $1.95 \mathrm{~g}$ & $39 \mathrm{~g}$ \\
\hline Soluble fibres & $0.4 \mathrm{~g}$ & $8 \mathrm{~g}$ \\
\hline Insoluble fibres & $1.55 \mathrm{~g}$ & $31 \mathrm{~g}$ \\
\hline Lignans & $25-50 \mathrm{mg}$ & $500-1000 \mathrm{mg}$ \\
\hline
\end{tabular}

The lignans and ALA in flax help prevent inflammation that affects the body's immune system. Linseed in the diet may be useful in the treatment of such immune disorders as rheumatoid arthritis, psoriasis and lupus. Linseed Oil increases the body's production of energy. Linseed Oil facilitates weight loss in persons afflicted with Obesity. Flax Seed Oil improves Stamina (by increasing the production of Energy). The metabolism of omega-3's From EPA, DHA and ALA play important role in the production of the same eicosanoids (thromboxane, leukotrienes, prostaglandins), this metabolism is directed to its effect on chronic vascular disease (Andrew et al., 2006). Linseed Oil shortens the time being necessary for fatigued muscles to recover after exertion. Flax Seed Oil alleviates the symptoms of Rheumatoid Arthritis. This Oil accelerates the healing of sprains. Alpha- linolenic acid, prevent excessive bone turn-over when consumption of foods rich in this omega-3 fatty acids in the diet (Griel et al., 2006). Linseed Oil effectively treats some cases of depression, improves the Mental Function of elderly people. Linseed Oil is beneficial in the treatment of and often improves the symptoms of Multiple Sclerosis. This Oil improves the behavior of Schizophrenics. Linseed Oil alleviates some cases of Asthma. Linseed Oil alleviates some cases of PréMenstrual Syndrome (PMS). Flax Seed Oil makes Pregnancy less event full, makes deliveries easier and produces healthier offspring. Phyto-estrogens are plant-derived compounds (i.e., isoflavones) that have a similar chemical structure to endogenous estrogen with the potential to act like estrogen on bone tissue (Miksicek, 1994). Linseed/ flaxseed are the most common sources of phytoestrogens.

The protective effects of phytoestrogens on 
bone loss have been reported from only 2 human Feeding trials (Potter et al., 1998; Alekel et al., 2000). Linseed Oil accelerates the healing of bruises. It is helpful in the treatment of eczema and Psoriasis. Linseed Oil increases the strength of the nails and strengthens nails that break easily. Supplementation of Flaxseed Oil Diminishes Skin Sensitivity and Improves Skin Barrier Function and Condition. (Neukam, 2010). EPA has anti-inflammatory properties (Simopoulos, 2004). The clinical significance of omega fatty acids lies primarily in the role they play in inflammatory events in the body. Indeed, the interplay between proinflammatory molecules derived from omega6 fatty acid PUFAs and the antiinflammatory actions of molecules derived from omega-3 PUFAs underlies significant cardiovascular benefits attributable to increasing ones consumption of omega-3 PUFAs while at the same time decreasing consumption of omega-6 PUFAs (Kapoor and Huang, 2006).

\section{References}

Alekel DL, Germain AS, Peterson CT, Hanson KB, Stewart JW, and Toda T. Isoflavone-rich soyprotein isolate attenuates bone loss in the lumbar spine of perimenopausal women. Am J Clin Nutr. 2000; 72: 844-52.

Andrew Weil, MD. et al., "Spontaneous Healing". Griel AE, J Soc Integr Oncol. summer. 2006; 5(3): 106-12.

Anonymous. Oil World Statistics Update. Oil World. 2000; 31: 9-10.

Chung MWY, Lei B, Li-Chan ECY. Isolation and structural characterization of the major protein fraction from NorMar flaxseed (Linum usitatissimum L.). Food Chem. 2005; 90: 271-279.

Chung MWY, Lei B, Li-Chan ECY. Isolation and structural characterization of the major protein fraction from NorMar flaxseed (Linum usitatissimum L.). Food Chem. 2005; 90: 271-279.

Diederich sen, A. and Richards, K. Cultivated flax and the genus Linnum L. taxonomy and gerplasm conservation. In Muir, A. D. and Westcott, N. D. (Eds). Flax, The genus Linum, 2003; p. 22-54. London: Taylor \& Francis.

El-Beltagi HS, Salama ZA, El-Hariri DM. Evaluation of fatty acids profile and the content of some secondary metabolites in seeds of different flax cultivars (Linum usitatissimum L.). General Applied Plant Physiology. 2007; 33: 187-202.

El-Beltagi HS, Salama ZA, El-Hariri DM. Evaluation of fatty acids profile and the content of some secondary metabolites in seeds of different flax cultivars (Linum Usitatissimum L.). General Applied Plant Physiology. 2007; 33: 187-202.

Gan, Y., Basnyat, P., McDonald, C.L., Campbell, C.A., Liu, L. Water use and distribution profile under pulse and oilseed crops in semiarid northern high latitude areas. Agric. Water Manage. 2009; 96, 337-348.

Gill, K.S.Flax. Indian Council of Agricultural Research, New Delhi, India. 1987; $386 \mathrm{p}$.

Green, A.G., Chen, Y., Singh, S.P., Dribnenki,. Flax. In: Chittaranjan, K., Hall, T.C. (Eds.),Compendium of Transgenic Crop Plants: Transgenic Oilseed Crops. Blackwell Publishing Ltd, Chicester, UK, pp. 2008;200226.

Ho C, Cacace J, Mazza G. Extraction of lignans, proteins and carbohydrates from flaxseed meal with pressurized low polarity water. LWT-Food Sci Technol. 2007; 40: 1637-1647.

Johnston A.M., Tanaka D.L., Miller P.R., Brandt S.A., Nielsen D.C., Lafond G.P., Riveland N.R.. Oilseed crops for 
semiarid cropping systems in the northern Great Plains. Agron. J. 2002; 94: 231-240.

Kimura Y, Takaku T, Nakajima S, Okuda H. Effects of carp and tuna oils on 5fluorouracilinduced antitumor activity and side effects in sarcoma 180bearing mice. Lipids; 2001; 36: 353 359.

Klimek A., Zając T. Produkcyjność grochu (Pisum sativum L.) natal postępu hodowlanego. / Productivity of pea (Pisum sativum L.) in view of the progress in plant breeding. Adv. Agric. Sci. 2009; 1: 77-91.

Kris-Etherton PM, Taylor DS, Yu-Poth S, Huth P, Moriarty K, Fishell V, et al., Polyunsaturated fatty acids in the food chain in the United States. See comment in PubMed Commons below Am J Clin Nutr. 2000; 71: 179S-88S.

Kris-Etherton PM, Taylor DS, Yu-Poth S, Huth P, Moriarty K, Fishell V, et al., Polyunsaturated fatty acids in the food chain in the United States.

Miksicek RJ. Interaction of naturally occurring nonsteroidal estrogens with expressed recombinant human estrogen receptor. J Steroid Biochem Mol Bio. 1994; 49:153-60.

Morris DH. Flax Primer, A Health and Nutrition Primer. Flax Council of Canada. 2007; 9-19.

Morris DH. Flax Primer, A Health and Nutrition Primer. Flax Council of Canada. 2007; 9-19.

Oomah BD, Berekoff B, Li-Chan C, Mazza G, Kenaschuk E, Duguid S. Cadmium-binding protein components of flaxseed: Influence of cultivar and location. Food Chem. 2007; 100: 318325.

Peterson, J., Dwyer, J., Adlercreutz, H., Scalbert, A., Jacques, P., and McCullough, M. L. Dietary lignans: physiology and potential for cardiovascular disease risk reduction. Nutrition Reviews, 2010; 68(10), 571603.

Potter SM, Baum JA, Teng H, Stillman RJ, Shay NF, Erdman JW Jr. Soy protein and isoflavones: their effects on blood lipids and bone density in postmenopausal women. American Journal of Clinical Nutrition; 1998; 68:1375S-9S.

Rabetafika HN, Van Remoortel V, Danthine S, Paquot M, Blecker C. Flaxseed proteins: food uses and health benefits. Int. J. Food Sci. Technol. 2011; 46: 221-228. 24.

Rabetafika HN, Van Remoortel V, Danthine S, Paquot M, Blecker C. Flaxseed proteins: food uses and health benefits. Int. J. Food Sci. Technol. 2011; 46: 221-228.

Rubilar M, Gutierrez C, Verdugo M, Shene C, Sineiro J. Flaxseed as a source of functional Ingredients. J Soil Sci Plant Nutr. 2010; 10: 373-377.

Rubilar M, Gutierrez C, Verdugo M, Shene C, Sineiro J. Flaxseed as a source of functional Ingredients. J Soil Sci Plant Nutr. 2010; 10: 373-377.

Ryan AM, Reynolds JV, Healy L. "Enteral nutrition enriched with eicosapentaenoic acid (EPA) preserves lean body mass following esophageal cancer surgery: results of a doubleblinded randomized controlled trial". Ann. Surg. 2009; 249(3): 355-63.

Sangiovanni JP, Chew EY. The role of omega-3 long chain polyunsaturated fatty acids in heath and disease of the retina. Progr Retin Eye Res. 2005; 24: 87-138.

Simopoulos AP. Omega-6/omega-3 essential fatty acid ratio and chronic diseases. Food Rev Int; 2004; 20: 77-90.

Simopoulos AP. The importance of the ratio of omega-6/omega-3 essential fatty acids. See comment in PubMed 
Commons below Biomed Pharmacother. 2002; 56: 365-379.

Simopoulos AP. The importance of the ratio of omega-6/omega-3 essential fatty acids. See comment in PubMed Commons below Biomed Pharmacother. 2002; 56: 365-379.

Singh KK, Mridula D, Rehal J, Barnwal P. Flaxseed: a potential source of food, feed and fiber. See comment in PubMed Commons below Crit Rev Food Sci Nutr. 2011; 51: 210-222.

Singh KK, Mridula D, Rehal J, Barnwal P. Flaxseed: a potential source of food, feed and fiber. See comment in PubMed Commons below Crit Rev Food Sci Nutr. 2011; 51: 210-222.

Vaisey-Genser, M. and Morris, D.H. Introduction: history of the cultivation and uses of flaxseed. In Muir, A. D. and Westcott, N. D. (Eds). Flax: The genus Linum. London: Taylor \& Francis. 2003. Pp. 1-2.

Vromans,J. Molecular Genetic Studies in Flax (Linum usitatissimum L.) (Ph.D. thesis). Wageningen University, Wageningen, The Netherlands, 2006; $226 \mathrm{p}$.

Wakjiraa. Labuschange M.T., Hugo A. Variability in oil content and fatty acid composition of Ethiopian and introduced cultivars of linseed. National Journal. Sci. Food Agric. 2004; 84: 601-607.

Winter R. Vitamin E: Your Protection Against Exercise Fatigue, Weakened Immunity, Heart Disease, Cancer, Aging, Diabetic Damage, Environmental Toxins. Crown Publishing Group. 2013.

\section{How to cite this article:}

Santosh Kumar, J.K. Singh and Akhilesh Vishwakarma. 2018. Importance of Linseed Crops in Agricultural Sustainability. Int.J.Curr.Microbiol.App.Sci. 7(12): 1198-1207. doi: https://doi.org/10.20546/ijcmas.2018.712.149 